\title{
Profil Nyeri Kepala pada penderita Covid-19 di RSUD dr. Chasbullah Abdulmajid Kota Bekasi
}

\author{
Fitriani Tri Rahayu ${ }^{1}$, Tranggono Yudo Utomo ${ }^{2}$ \\ 1. Dokter RSUD dr. Chasbullah Abdulmadjid Kota Bekasi \\ 2.Staff Pengajar Departemen Neurologi FK UKI Jakarta \\ 2.Spesialis Saraf RSUD Dr. Dr.Chasbullah Abdulmajid Kota Bekasi
}

\begin{abstract}
ABSTRAK
Pendahuluan: SARS-CoV-2 atau COVID-19 merupakan wabah baru yang menjadi Public Health Emergency of International Concern (PHEIC). Nyeri kepala merupakan manifestasi yang paling sering, memiliki heterogenitas tinggi, dapat muncul pertama dan sebagai gejala tunggal. Nyeri kepala dapat menjadi perhatian dini terhadap identifikasi dini infeksi, namun hingga saat ini tidak ada data sistematis dari karakteristik nyeri kepala akibat COVID-19.
\end{abstract}

Tujuan: Untuk mengetahui frekuensi dan karakteristik nyeri kepala pada pasien COVID-19

Metode: Studi cross-sectional pada pasien COVID-19 dengan keluhan nyeri kepala di Instalansi Gawat Darurat (IGD) RSUD dr. Chasbullah Abdulmadjid Kota Bekasi. Teknik pengambilan sampel adalah total sampling menggunakan data sekunder rekam medis periode Oktober-Desember tahun 2020.

Hasil: Dari 69 pasien dengan keluhan nyeri kepala terkonfirmasi COVID-19, mayoritas adalah perempuan (62\%) dan kelompok usia terbanyak 40-60 tahun (71\%). Nyeri kepala terkait COVID-19 pada sebagian besar pasien adalah nyeri kepala bilateral $(49,28 \%)$, intensitas sedang $(52,17 \%)$, dan bersifat menekan/mengikat $(40,56 \%)$.

Kesimpulan: Nyeri kepala terkait COVID-19 adalah keluhan yang sering ditemui di Instalansi Gawat Darurat (IGD) RSUD dr. Chasbullah Abdulmajid dengan lokasi nyeri paling banyak pada daerah temporal, intensitas nyeri sedang dan bersifat nyeri menekan/ mengikat.

Kata Kunci: COVID-19, profil, dan nyeri kepala

\section{ABSTRACT}

Introduction: SARS-CoV-2 or COVID-19 is a new outbreak that has become the Public Health Emergency of International Concern (PHEIC). Headache is the most frequent manifestation, has high heterogeneity, can appear early and as a single symptom. Headache can be an early concern for early identification of infection, but to date there are no systematic data on the characteristics of headache due to COVID-19.

Aim: To study the frequency and characteristics of headaches in COVID-19 patients.

Method: A cross-sectional study of headache due to COVID-19 infection was conducted in the Emergency Department Neurology Hospital dr. Chasbullah Abdulmadjid. The sampling technique was total sampling using secondary data from medical records in October-December 2020.

Result: Of the 69 confirmed COVID-19 with headache, the majority was women (62\%) and the largest age group was 40-60 years (71\%). The characteristic of headaches associated with COVID-19 was bilateral (49.28\%), moderate-intensity (52.17\%), and tightening/pressing (40.56\%).

Conclusion: Headache is a very prevalent COVID-19 symptom among patients presenting to the emergency room in dr. Chasbullah Abdulmadjid Hospital and most located in temporal region, moderate pain intensity, with tightening/pressing sensation.

Keywords: COVID-19, profile, and headache 


\section{Pendahuluan}

Selama 6 minggu pertama dekade baru, SARS-CoV-2, yang dikenal sebagai COVID-19 telah menyebar dari Republik Rakyat China ke 20 negara lain. Pada 30 Januari 2020 menyusul rekomendasi dari Emergency Committee, Dirjen WHO (World Health Organization) menyatakan bahwa wabah tersebut merupakan Public Health Emergency of International Concern (PHEIC). ${ }^{1}$

Secara global, ada 108.153.741 kasus COVID-19 yang dikonfirmasi, termasuk 2.381.295 kematian, dilaporkan ke WHO. ${ }^{2}$ Di Indonesia ada 1,223,930 kasus terkonfirmasi, tren nasional masih menunjukkan arah naik ${ }^{3}$ dan masuk dalam kategori community transmission ${ }^{4}$, dimana orang telah terinfeksi virus di suatu daerah, termasuk beberapa orang yang tidak yakin bagaimana atau di mana mereka tertular. ${ }^{5}$ Mengenai penularannya, viral load pada index cases adalah pendorong utama penularan SARS-CoV-2. ${ }^{6}$

Studi menunjukkan bahwa COVID-19 memiliki banyak gejala seperti demam, nyeri kepala, anosmia, batuk, kelelahan dan dyspnea. $^{7,8}$ Nyeri kepala, terutama yang baru timbul pada pasien yang tidak menderita kondisi ini, harus menjadi perhatian dini terhadap kemungkinan terinfeksi COVID-19. ${ }^{9}$ Beberapa studi dan tinjauan menekankan bahwa gejala neurologi paling umum adalah nyeri kepala, diikuti dengan demam tinggi. Selain itu, nyeri kepala juga dapat muncul sebagai gejala tunggal dan pertama yang muncul dari infeksi COVID-19. Nyeri kepala yang timbul pada pasien COVID-19 sebanyak $10,9 \%$ dan memiliki heterogenitas yang tinggi. ${ }^{10}$ Nyeri kepala yang dialami bisa seperti migraine, atau dengan karakter nyeri kepala yang tidak biasa, umumnya sangat intens dan difus. ${ }^{11,12}$

Dalam sebuah studi observasioanl dan serial kasus, nyeri kepala terkait COVID-19 dideskripsikan sebagai nyeri dengan onset akut, biasanya muncul dengan manifestasi yang berbeda dengan riwayat nyeri kepala sebelumnya ${ }^{6,9}$. Namun, tidak ada data sistematis dari karakteristik nyeri kepala akibat COVID-19 hingga saat ini. Permasalahan lainnya yakni efek atau dampak psikologis dari COVID-19 dapat menyebabkan beban nyeri kepala yang lebih besar, diikuti dengan permasalahan isolasi pada pasien dan masalah ini masih belum diinvestigasi dengan baik.

Oleh karena itu, pertanyaan mendetail mengenai klinis nyeri kepala pada pasien yang berada di instalansi gawat darutat merupakan langkah penting dalam 
mengidetifikasi dengan tepat adanya infeksi pada sebagian pasien.

Penelitian ini bertujuan untuk menilai frekuensi dan karakteristik nyeri kepala terkait COVID-19 sehingga bisa menjadi langkah awal untuk diagnosis dan tatalaksana pada pasien covid-19

\section{Metode}

Penelitian ini merupakan studi crosssectional yang diperoleh dari data sekunder rekam medik penderita COVID-19 yang datang ke Instalansi Gawat Darurat (IGD) RSUD dr. Chasbullah Abdulmadjid Kota Bekasi periode Oktober-Desember tahun 2020. Penelitian ini menggunakan metode total sampling, dengan kriteria inlusi: semua pasien terdiagnosis COVID-19 dan terkonfirmasi positif SARS-CoV-2, compos mentis, tidak memiliki riwayat gangguan neurologi, dan memiliki rekam medis lengkap. Data diekstraksi dan dianalisis berdasarkan frekuensi usia, jenis kelamin, dan karakteristik klinis. Penggunaan rekam medis dalam penelitian ini telah sesuai dengan regulasi rumah sakit serta kerahasiaan identitas subjek dijamin.

\section{Hasil}

Didapatkan data sebanyak 69 pasien kemudian dilakukan penilaian dan analisis. Semua pasien memiliki gejala respirasi (seperti batuk dan sesak ringan) dan telah dilakukan konfimasi melalui RT-PCR dan swab orofaringeal yang positif terhadap SARS-CoV-2. Tidak ada pasien yang mengalami gangguan kesadaran maupun adanya tanda meningeal atau neurologis focal. Pasien tidak menjalani pemeriksaan CT scan kepala, MRI, maupun analisis CSF (cairan serebrospinal) karena tidak menunjukkan adanya tanda bahaya (warnin sign) untuk komplikasi neurologis COVID19.

\section{Distribusi Jenis Kelamin}

Proporsi tertinggi pasien dengan infeksi COVID-19 dengan klinis nyeri kepala adalah perempuan sebanyak 43 orang (62\%) sedangkan pasien laki-laki 26 orang (38\%). Distribusi proporsi berdasarkan jenis kelamin di atas dapat dilihat pada Gambar 1.

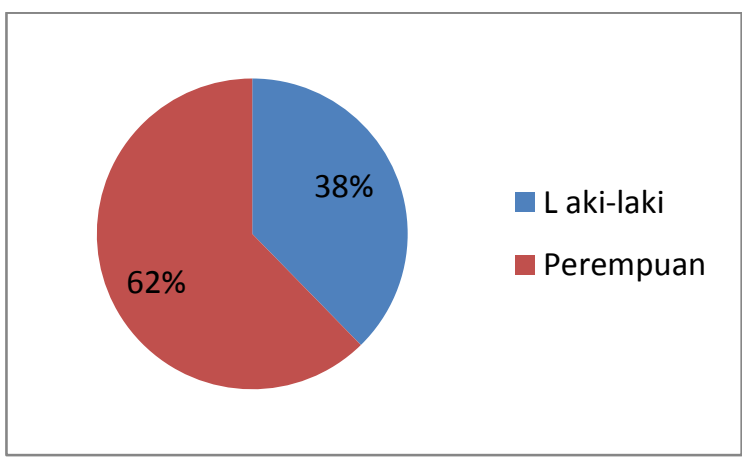

Gambar 1. Distribusi Proporsi Pasien COVID19. Berdasarkan Jenis Kelamin. Diketahui bahwa perempuan merupakan mayoritas penderita infeksi COVID-19 dengan keluhan nyeri kepala $(62 \%)$.

\section{Distribusi Usia}

Dari 69 pasien COVID-19, proporsi tertinggi berada pada kelompok usia 40-60 tahun sebanyak 49 orang $(71 \%)$, diikuti oleh kelompok usia <40 tahun sebanyak 13 orang $(18,84 \%)$ dan proporsi terendah berada pada kelompok usia >60 tahun sebanyak 7 orang $(10,14 \%)$. Distribusi 
proporsi berdasarkan usia di atas dapat dilihat pada Gambar 2.

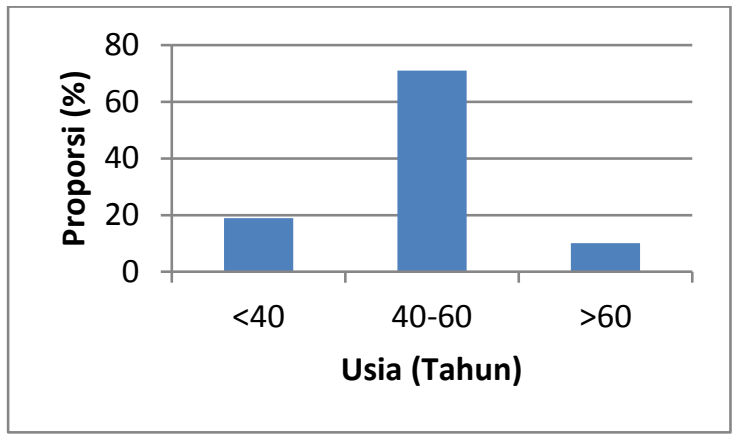

Gambar 2. Distribusi Proporsi Pasien COVID19 Berdasarkan Usia. Diketahui bahwa kelompok usia 40-60 tahun merupakan kelompok dominan penderita infeksi COVID19 dengan klinis nyeri kepala (71\%).

\section{Distribusi Karakteristik Nyeri Kepala}

Sebanyak 69 orang dengan infeksi COVID19 memiliki gejala nyeri kepala. Nyeri kepala akbat infeksi COVID-19 memiliki berbagai manifestasi klinis baik dari lokasi, intensitas nyeri, dan sifat nyerinya. Untuk lebih mengetahui proporsi dari masingmasing pada Tabel 1 disajikan data karakteristik dari nyeri kepala terkait COVID-19.

Tabel 1. Karakteristik Nyeri Kepala Terkait COVID-19

\begin{tabular}{l|c}
\hline \multicolumn{1}{c|}{ Karakteristik } & $(\mathbf{n = 6 9 )}$ \\
\hline Onset nyeri kepala & 2 hari \\
\hline Tidak ada riwayat & Ya \\
nyeri kepala & \\
\hline Lokasi nyeri kepala & \\
Frontal & $13(18,84 \%)$ \\
Temporal & $15(21,74 \%)$ \\
Parietal & $5(7,25 \%)$ \\
Oksipital & $2(2,89 \%)$ \\
Nyeri bilateral & $34(49,28 \%)$ \\
\hline
\end{tabular}

\begin{tabular}{l|c}
\hline $\begin{array}{l}\text { Intensitas nyeri } \\
\text { kepala }\end{array}$ & \\
Ringan & $2(2,89 \%)$ \\
Sedang & $36(52,17 \%)$ \\
Berat & $31(44,92 \%)$ \\
\hline Sifat nyeri kepala & \\
Berdenyut & $15(21,74 \%)$ \\
Menekan /mengikat & $28(40,56 \%)$ \\
Menusuk & $2(2,89 \%)$ \\
(stabbing) & $14(20,29 \%)$ \\
Mual (nausea) & $5(7,25 \%)$ \\
Muntah (vomiting) & $3(4,35 \%)$ \\
Fotofobia & $2(2,89 \%)$ \\
Fonofobia & \\
\hline
\end{tabular}

Nyeri kepala pada COVID-19 umumnya muncul selama 2 hari dengan lokasi nyeri paling banyak pada daerah temporal (15\%), intensitas nyeri sedang $(52,17 \%)$ dan bersifat nyeri menekan/ mengikat (28\%).

Pasien melaporkan adanya nyeri kepala pada hari kedua gejala. Lokasi nyeri kepala terbanyak adalah nyeri bilateral, dialami oleh 34 pasien $(49,28 \%)$ dan lokasi nyeri daerah oksipital adalah paling jarang, ditemukan hanya pada 2 orang $(2,89 \%)$.

Intensitas nyeri kepala paling sering adalah intensitas sedang pada 36 orang $(52,17 \%)$, diikuti nyeri intesitas berat pada 31 orang $(44,92 \%)$, dan intensitas ringan hanya pada 2 orang $(2,89 \%)$.

Nyeri kepala yang bersifat menekan / mengikat paling banyak dikeluhkan dengan jumlah pasien 28 orang (40,56\%), sedangkan nyeri kepala yang bersifat menusuk (stabbing) dan fonofobia paling jarang dikeluhkan, yakni hanya pada 2 orang masing-masing $(2,89 \%)$.

\section{Pembahasan}




\section{Karakteristik Pasien}

Pada penelitian ini, pasien perempuan menempati proporsi terbanyak yakni $62 \%$ sebagai penderita COVID-19 dengan gejala nyeri kepala. Meskipun laporan pertama di Cina menunjukkan dominasi pasien COVID-19 adalah laki-laki, penelitian terbaru menunjukkan bahwa perempuan mungkin berisiko lebih tinggi untuk COVID-19. Hal ini sesuai dengan penelitian sebelumnya yang dilakukan oleh Kopel et $a l^{13}$ bahwa $37,7 \%$ penderita COVID-19 adalah laki-laki sedangkan $62,3 \%$ adalah perempuan. Sebuah studi cross-sectional oleh Membrilla et $\mathrm{al}^{14}$ mengenai nyeri kepala sebagai tanda cardinal infeksi COVID-19 menyebutkan bawa perempuan mendominasi dengan proporsi sebanyak 58,7\%. Studi lain di Brazil oleh Arisi et $a l^{15}$ pada populasi di Italia pasca lockdown juga menyebutkan bahwa penderita COVID-19 proporsi terbesar adalah perempuan. Ada kemungkinan bahwa peningkatan infeksi perempuan paruh baya pasca lockdown ini disebabkan lebih besar porsi perempuan yang merupakan petugas kesehatan, dibandingkan dengan pria (84\% untuk wilayah Eropa). Pada beberapa rentang usia, perempuan lebih mungkin terinfeksi daripada laki-laki. Dalam studi serupa di Kota Qingdao, Cina, meneliti 44 pasien COVID-19, menunjukkan $66 \%$ adalah perempuan. ${ }^{16}$ Dominasi perempuan yang dilaporkan dalam penelitian ini kemungkinan karena ukuran sampel yang kecil selama tahap awal epidemi COVID19. Hasil ini berbeda dengan data China yang diperkirakan $\sim 51 \%$ dari pasien COVID-19 adalah laki-laki. ${ }^{13}$

Studi lain yang bertentangan ditemukan di Brazil oleh Filho et $a l^{12}$ dimana pasien COVID-19 dengan gejala nyeri kepala $63 \%$ adalah laki-laki dan studi oleh Freni et $a l^{17}$ dimana 30 dari 50 penderita COVID-19 adalah laki-laki pada populasi Eropa dan Asia. Dapat dihipotesiskan bahwa dominasi gender yang terbalik ini mungkin berhubungan dengan penyakit penyerta seperti aterosklerosis dan hipertensi yang lebih sering terjadi pada pria. Namun, jumlah perempuan dengan nyeri kepala terkait COVID-19 juga masih lebih tinggi dibandingkan migraine biasa. ${ }^{10}$ Oleh karena itu, temuan ini adalah titik mencolok yang membutuhkan elaborasi lebih lanjut. Selain itu, perbedaan tersebut mungkin mencerminkan perbedaan kegiatan sosial dari negara lain. Oleh karena itu, disparitas gender pada COVID-19 dapat menjadi cerminan perbedaan sosial dan budaya antara negara yang berbeda. ${ }^{13}$

Berdasarkan hasil analisis penelitian ini, dari 69 pasien COVID-19, proporsi tertinggi berada pada kelompok usia 40-60 tahun sebanyak 49 orang (71\%) dan 
proporsi terendah pada kelompok usia $>60$ tahun sebanyak 7 orang $(10,14 \%)$. Sebuah studi cross-sectional oleh Membrilla et al ${ }^{14}$ mengenai nyeri kepala sebagai tanda cardinal infeksi COVID-19 menyebutkan bahwa rata-rata keluhan muncul pada rerata usia 40-50 tahun. Penelitian lain oleh Caronna et $\mathrm{al}^{18}$ menyebutkan bahwa errata usia penderita COVID-19 dengan gejala predominan nyeri kepala ada berusia 55 tahun, dengan nyeri kepala berat berada pada rentang usia $44.8 \pm 14.9$ tahun dan nyeri kepala sedang pada rentang $52.5 \pm 15.1$ tahun. Data demografik dalam sebuah studi berbasis survey juga menyebutkan bahwa penderita COVID-19 dengan gejala nyeri kepala paling banyak diderita oleh orang berusia 40 tahun. ${ }^{10}$ Pasien dengan usia tua menempati proporsi paling rendah. Pada usia yang lebih tua, adanya ekspresi berlebihan pada gen terkait-X mungkin menjadi alasan. Perempuan pada usia tua lebih terlindungi oleh infeksi karena sistem kekebalan yang kuat, dan mereka memiliki tingkat ACE2 yang lebih tinggi. Selain itu, orang-orang pada usia tua biasanya mengkonsumsi vitamin D untuk membantu transisi menopause dan mencegah terjadinya osteoporosis Diketahui bahwa kadar vitamin D yang mencukupi akan berkontribusi untuk mengurangi inflamasi dan infeksi saluran pernapasan akut. ${ }^{15,19}$
Namun, studi lain di Italia bertentangan dan menyebutkan bahwa infeksi banyak terjadi pada orang dengan usia tua (> 60 tahun). Perubahan cepat menuju kejadian ini diyakini disebabkan oleh penyebaran virus yang tidak acak pada orang usia tua. ${ }^{15}$

\section{Karakteristik Nyeri Kepala}

Pada studi ini, 69 partisipan dengan infeksi COVID-19 yang terkonfimasi melalui RTPCR dan swab orofaringeal melaporkan adanya keluhan nyeri kepala selama pandemi. Karakteristik nyeri kepala beserta lokasi dan intensitasnya telah ditunjukkan pada Tabel 1.

Manifestasi neurologis yang sering dilaporkan pada pasien dengan infeksi COVID-19 adalah anosmia dan ageusia (85,6 dan 88,0\%), nyeri kepala (6,4$32,0 \%)$, dan mialgia (11-52\%), diikuti dengan confusion (9.0\%), dizziness (9.0\%), kejang $(7.0 \%)$, dan stroke. ${ }^{20}$ Perlu diketahui bahwa keluhan nyeri kepala ini seringkali terabaikan karena pasien dan pemeriksa lebih berfokus pada manifestasi klinis pada sistem pernafasan.

Prevalensi nyeri kepala ditemukan pada $10,9 \%(8,6-13,5 \%)$ dalam studi metaanalisis dari 6486 pasien, di mana prevalensinya berkisar dari $3,5-34 \% .^{21}$ Tiga studi yang berfokus pada gejala neurologis pada pasien yang dirawat dengan COVID-19 melaporkan adanya 
frekuensi nyeri kepala yang lebih tinggi $27 \%^{22}, 39 \%^{23}$ dan $43 \%^{24}$. Sebuah studi kohort retrospektif yang menilai prognostik nyeri kepala mengemukakan frekuensi sebanyak $24 \%^{25}$ dan sebuah studi multisenter di Eropa yang menilai gejala pasien rawat inap di rumah sakit melaporkan frekuensi nyeri kepala sebanyak $70 \% .^{26}$

Pada umumnya nyeri kepala yang menyertai Infeksi sistemik biasanya tidak spesifik, tanpa ciri khas pembeda atau karakteristik tertentu. ${ }^{27}$ Meskipun nyeri kepala yang difus dan intensitas sedang atau berat masuk dalam kriteria ICHD-3 "Nyeri kepala akut dikaitkan dengan infeksi virus sistemik", klinis tersebut tidak wajib ada untuk diagnosis. ${ }^{26}$ Pada penelitian ini menunjukkan bahwa mayoritas pasien memiliki nyeri kepala bilateral $(49,28 \%)$, intensitas sedang $(52,17 \%)$, dan bersifat menekan/mengikat (40,56\%).

Hasil penelitian ini sejalan dengan studi oleh Uygun et $a l^{10}$ bahwa nyeri kepala dengan tipe bilateral, long-lasting, dan resisten terhadap analgesik, serta dialami oleh laki-laki lebih sering pada pasien dengan COVID-19 (166 orang; 85\%), sejalan dengan keluhan anosmia/ageusia dan gangguan pencernaan. ${ }^{10}$ Klinis tersebut bisa sangat membantu untuk mendiagnosis nyeri kepala terkait pasien positif atau negatif COVID-19. Penelitian sebelumnya juga menyebutkan bahwa sifat nyeri kepala yang berdenyut pada pasien COVID-19, lebih terlihat pada pasien dengan riwayat nyeri kepala sebelumnya. Hal tersebut mungkin menunjukkan bahwa latar belakang individu penting dalam presentasi nyeri kepala terkait COVID-19. ${ }^{10}$ Studi crossectional lain yang sejalan yakni oleh Membrilla et $\mathrm{al}^{14}$ menunjukkan hasil dimana mayoritas pasien dengan konfirmasi positif COVID-19 memiliki fitur nyeri kepala bilateral $(86 / 99,86.9 \%)$ dan diikuti dengan nyeri kepala frontal atau holokranial (34/99, 34.3\%), bersifat menekan/ mengikat (40,7\%) dengan intensitas sedang-berat. Pasien juga menunjukkan kecenderungan untuk prostration (41/99, 41.4\%), fotofobia (29/99, 29.3\%), dan fonofobia (27/99, $27.3 \%)$.

Pasien dengan migraine cenderung memiliki keluhan nyeri kepala yang lebih awal, lebih lama, dan lebih berat. $^{27}$ Frekuensi nyeri kepala terkait COVID-19 lebih tinggi pada pasien dengan riwayat nyeri kepla primer, dehidrasi dan dengan komorbid. Sementara itu, intensitas nyeri yang tinggi juga dikaitkan dengan jenis kelamin perempuan, demam, dan dehidrasi. ${ }^{10,27}$

Infeksi COVID-19 mungkin berperan sinergis dalam nosisepsi pada pathways yang sama dari kompleks 
trigeminovaskular sebagai penyebab nyeri kepala primer seperti migraine. Namun, perbedaan karakteristik seperti nyeri kepala berdenyut, menekan, bahkan menusuk (stabbing) mengindikasikan bahwa ada lebih dari satu mekanisme yang terlibat dalam nyeri kepala terkait COVID-19. ${ }^{10,27}$ Tentunya hal tersebut masih perlu eksplorasi lebih lanjut.

Patogenesis nyeri kepala yang dikaitkan dengan infeksi sistemik masih belum dijelaskan dengan baik. Beberapa hipotesis menyebutkan bahwa mikroorganisme mengaktifkan mediator inflamasi dan nosiseptif yang merangsang nyeri kepala, seperti nitric oxide, prostaglandin dan sitokin. ${ }^{27}$, Hal tersebut juga berlaku pada infeksi COVID-19 yang diikuti adanya pelepasan sejumlah besar sitokin proinflamasi seperti IL-1b, IL-6, dan TNF-a, yang terlibat dalam berbagai keadaan nyeri patologis. ${ }^{27}$

Gejala mirip migrain seperti fotofobia, fonofobia, dan memberat dengan ativitas fisik sering terjadi, baik pada pasien dengan riwayat migrain dan non-migrain. Fakta ini bisa dijelaskan oleh mekanisme patogenik konvergen antara migrain dan nyeri kepala terkait COVID-19. Sitokin proinflamasi, termasuk interleukin (IL) $1 \beta$, IL-6, IL-8, dan tumor necrosis factor $\alpha$, telah ditemukan terlibat dalam nyeri akibat migrain dan juga dilepaskan dalam reaksi imunologis terhadap virus influenza, rhinovirus, $\mathrm{CoV}$, dan patogen lainnya. ${ }^{14}$

Studi yang dilakukan oleh Magdy et $a l^{27}$ mengenai adanya respon pada pemberian steroid pada pasien terkonfimrasi COVID$19(40,7 \%)$ mungkin merupakan indikasi imunologi / mekanisme inflamasi terhadap adanya klinis nyeri kepala terkait COVID19. Meskipun tidak ditemukan hubungan yang signifikan secara statistik antara penggunaan steroid terhadap frekuensi, durasi atau intensitas nyeri kepala terkait COVID-19. ${ }^{27}$ Pendapat lain menyebutkan bawa demam, bagian dari fitur klinis infeksi sitemik, bisa menjadi salah satu pemicu adanya nyeri kepala. Mediator inflamasi utama SARS-COV-2 (IL1 dan IL6) merangsang hipotalalamus dan menginduksi demam. Sesuai sengan studi sebelumnya bahwa pasien COVID-19 dengan demam lebih mungkin mengalami periode nyeri kepala terkait COVID-19, dibandingkan dengan pasien tanpa klinis demam. ${ }^{27}$ Namun, hasil tersebut tidak boleh dijadikan pedoman utama mengingat beberapa pasien $(30,2 \%)$ mengalami nyeri kepala tanpa adanya klinis demam. ${ }^{27}$

\section{Kesimpulan}

Karakteristik dari 69 orang yang datang di Instalasi Gawat Darurat (IDG) RSUD dr.Chasbullah Abdulmadjid Kota Bekasi menunjukkan mayoritas pasien COVID-19 
dengan keluhan nyeri kepala adalah perempuan (62\%) dengan kelompok usia terbanyak 40-60 tahun (71\%). Nyeri kepala terkait COVID-19 pada sebagian besar pasien adalah nyeri kepala bilateral $(49,28 \%)$, intensitas sedang $(52,17 \%)$, dan bersifat menekan/mengikat $(40,56 \%)$.

Nyeri kepala terkait COVID-19 merupakan salah satu gejala neurologis yang sering dilaporkan. Penelitian mengenai frekuensi dan karakteristik nyeri kepala terkait COVID-19 merupakan sebuah langkah awal untuk diagnosis dan tatalaksana yang tepat pada COVID-19. Studi multidisiplin dan kolaborasi antara pemerintah sebagai pengatur kebijakan dan pihak pelayanan kesehatan untuk berbagi informasi dan sosialisasi dirasa perlu kepada pasien dan masyarakat luas. Studi lanjut dimasa mendatang mengenai mekanisme patofisiologi pada masing-masing karakteristik nyeri kepala dan identifikasi gejala terkait dengan migraine perlu dilakukan untuk memberikan pemahaman yang lebih baik pada nyeri kepala terkait COVID-19.

\section{Ucapan Terimakasih}

Penulis mengucapkan apresasi tertinggi kepada $d r$. Tranggono Yudo Utomo, Sp.S (K) sebagai Spesialis Saraf RSUD dr. Chasbullah Abdulmajid Kota Bekasi dan Staff Pengajar Departemen Neurologi FK
UKI Jakarta, telah mengarahkan dalam membuat penelitian. Serta terima kasih kepada RSUD dr. Chasbullah Abdulmajid Kota Bekasi telah mengizinkan melakukan penelitian.

\section{Konflik Kepentingan}

Penulis menyatakan tidak ada potensi konflik kepentingan sehubungan dengan penelitian, kepenulisan, dan / atau publikasi penelitian ini.

\section{Daftar Pustaka}

1. WHO. COVID 19 Public Health Emergency of International Concern (PHEIC).; 2020.

2. WHO. WHO Coronavirus Disease (COVID-19) Dashboard. World Health Organization. https://covid19.who.int/. Published 2021.

3. Satuan Tugas Penanganan COVID19. Peta Sebaran Kasus Covid-19. https://covid19.go.id/peta-sebaran. Published 2021.

4. WHO. Situation by Country, Territory \& Area: Indonesia. World Health Organization. https://covid19.who.int/table.

Published 2021.

5. CDC. COVID-19 FAQ. Centers for Disease Control and Prevention. https://www.cdc.gov/coronavirus/20 19-ncov/faq.html. Published 2021.

6. Marks M, Millat P, Ouchi D, et al. Transmission of COVID-19 in 282 clusters in Catalonia, Spain: A cohort study. medRxiv. 2020;3099(20):1-8. doi:10.1101/2020.10.27.20220277 
7. Alimohamadi Y, Sepandi M, Taghdir M, Hosamirudsari $\mathrm{H}$. Determine the most common clinical symptoms in COVID-19 patients: A systematic review and metaanalysis. $J$ Prev Med Hyg. 2020;61(3):E304-E312.

doi:10.15167/2421-

4248/jpmh2020.61.3.1530

8. Alanazi E, Alashaikh A, Alqurashi S, Alanazi A. Identifying and ranking common COVID-19 symptoms from tweets in Arabic: Content analysis. J Med Internet Res. 2020;22(11):1-9. doi:10.2196/21329

9. Lippi G, Mattiuzzi C, Bovo C, Henry BM. Headache is an important symptom in patients with coronavirus disease 2019 (COVID19). Diagnosis. 2020;7(4):409-411. doi:10.1515/dx-2020-0048

10. Uygun Ö, Ertaş M, Ekizoğlu E, et al. Headache characteristics in COVID19 pandemic-a survey study. $J$ Headache Pain. 2020;21(1):1-10. doi:10.1186/s10194-020-01188-1

11. Toptan T, Aktan Ç, Başarı A, Bolay H. Case Series of Headache Characteristics in COVID-19: Headache Can $\mathrm{Be}$ an Isolated Symptom. Headache. 2020;60(8):1788-1792. doi:10.1111/head.13940

12. Rocha-Filho PAS, Magalhães JE. Headache associated with COVID19: Frequency, characteristics and association with anosmia and ageusia. Cephalalgia. 2020;40(13):1443-1451. doi:10.1177/0333102420966770

13. Kopel J, Perisetti A, Roghani A, Aziz M, Gajendran M, Goyal H. Racial and Gender-Based Differences in COVID-19. Front Public Heal. 2020;8(July):1-8. doi:10.3389/fpubh.2020.00418
14. Membrilla JA, de Lorenzo Í, Sastre M, Díaz de Terán J. Headache as a Cardinal Symptom of Coronavirus Disease 2019: A Cross-Sectional Study. Headache. 2020;60(10):2176-2191. doi:10.1111/head.13967

15. Ivan Arisi EM. Age and gender distribution of COVID-19 infected cases in Italian population. Res $S q$. 2020:1-16. https://doi.org/10.21203/rs.3.rs72021/v1.

16. Jia $\mathrm{J}, \mathrm{Hu} \mathrm{X}$, Yang $\mathrm{F}$, et al. Epidemiological Characteristics on the Clustering Nature of COVID-19 in Qingdao City, 2020: A Descriptive Analysis. Disaster Med Public Health Prep. 2020;14(5):643647. doi:10.1017/dmp.2020.59

17. Freni F, Meduri A, Gazia F, et al. Symptomatology in head and neck district in coronavirus disease (COVID-19): A possible neuroinvasive action of SARS-CoV2. Am J Otolaryngol - Head Neck Med Surg. 2020;41(5):102612. doi:10.1016/j.amjoto.2020.102612

18. Caronna E, Ballvé A, Llauradó A, et al. Headache: A striking prodromal and persistent symptom, predictive of COVID-19 clinical evolution. Cephalalgia. 2020;40(13):14101421.

doi:10.1177/0333102420965157

19. La Vignera $\mathrm{S}$, Cannarella $\mathrm{R}$, Condorelli RA, Torre F, Aversa A, Calogero AE. Sex-specific SARSCoV2 mortality: Among hormonemodulated ace 2 expression, risk of venous thromboembolism and hypovitaminosis D. Int $\mathrm{J}$ Mol Sci. 2020;21(8):5-10. doi:10.3390/ijms21082948

20. Mao L, Jin $\mathrm{H}$, Wang $\mathrm{M}$, et al. Neurologic Manifestations of 
Hospitalized Patients with Coronavirus Disease 2019 in Wuhan, China. JAMA Neurol. 2020;77(6):683-690.

doi:10.1001/jamaneurol.2020.1127

21. Pinzon RT, Wijaya VO, Buana RB, Al Jody A, Nunsio PN. Neurologic characteristics in coronavirus disease 2019 (COVID-19): A systematic review and metaanalysis. Front Neurol. 2020;11(May):1-11.

doi:10.3389/fneur.2020.00565

22. Karadaş Ö, Öztürk B, Sonkaya AR. A prospective clinical study of detailed neurological manifestations in patients with COVID-19. Neurol Sci. 2020;41(8):1991-1995. doi:10.1007/s10072-020-04547-7

23. Liguori C, Pierantozzi M, Spanetta $M$, et al. Subjective neurological symptoms frequently occur in patients with SARS-CoV2 infection. Brain Behav Immun. 2020;88:11-16. doi:10.1016/j.bbi.2020.05.037

24. Vacchiano V, Riguzzi P, Volpi L, et al. Early neurological manifestations of hospitalized COVID-19 patients. Neurol Sci. 2020;41(8):2029-2031. doi:10.1007/s10072-020-04525-z
25. Trigo J, García-Azorín D, Planchuelo-Gómez Á, et al. Factors associated with the presence of headache in hospitalized COVID-19 patients and impact on prognosis: A retrospective cohort study. $J$ Headache Pain. 2020;21(1):1-10. doi:10.1186/s10194-020-01165-8

26. Lechien JR, Chiesa-Estomba CM, Place $S$, et al. Clinical and epidemiological characteristics of 1420 European patients with mildto-moderate coronavirus disease 2019. J Intern Med. 2020;288(3):335-344.

doi:10.1111/joim.13089

27. Magdy R, Hussein M, Ragaie C, et al. Characteristics of headache attributed to COVID-19 infection and predictors of its frequency and intensity: A cross sectional study. Cephalalgia. 2020;40(13):14221431.

doi:10.1177/0333102420965140 